\title{
Genetic diversity in proteolytic enzymes and amino acid metabolism among Lactobacillus helveticus strains ${ }^{1}$
}

\author{
J. R. Broadbent, ${ }^{* 2}$ H. Cai,† R. L. Larsen, ${ }^{\star}$ J. E. Hughes,‡ D. L. Welker,‡ V. G. De Carvalho,§ T. A. Tompkins,§ \\ Y. Ardö,\# F. Vogensen,\# A. De Lorentiis,II M. Gatti,II E. Neviani,II and J. L. Steele† \\ *Department of Nutrition, Dietetics, and Food Sciences and Western Dairy Center, Utah State University, Logan 84322-8700 \\ †Department of Food Science, University of Wisconsin-Madison 53706 \\ ‡Department of Biology, Utah State University, Logan 84322-5305 \\ §Institut Rosell, Montreal, QC, Canada H4P 2R2 \\ \#University of Copenhagen, Rolighedsvej 30, DK-1958 Frederiksberg C, Denmark \\ IIDepartment of Genetics, Biology of Microorganisms, Anthropology, Evolution, University of Parma, Viale Usberti 11/A, 43100 Parma, Italy
}

\section{ABSTRACT}

Lactobacillus helveticus CNRZ 32 is recognized for its ability to decrease bitterness and accelerate flavor development in cheese, and has also been shown to release bioactive peptides in milk. Similar capabilities have been documented in other strains of Lb. helveticus, but the ability of different strains to affect these characteristics can vary widely. Because these attributes are associated with enzymes involved in proteolysis or AA catabolism, we performed comparative genome hybridizations to a CNRZ 32 microarray to explore the distribution of genes encoding such enzymes across a bank of $38 \mathrm{Lb}$. helveticus strains, including 2 archival samples of CNRZ 32. Genes for peptidases and AA metabolism were highly conserved across the species, whereas those for cell envelope-associated proteinases varied widely. Some of the genetic differences that were detected may help explain the variability that has been noted among $L b$. helveticus strains in regard to their functionality in cheese and fermented milk.

Key words: Lactobacillus, proteolysis, cheese flavor, bioactive peptide

\section{INTRODUCTION}

Lactobacillus helveticus is an obligately homofermentative lactic acid bacterium ( $\mathbf{L A B}$ ) that is widely used as a starter culture to manufacture yogurt and certain Swiss and Italian cheeses (Hassan and Frank, 2001; Gatti et al., 2004), and also as a flavor-enhancing adjunct culture for other cheese types (Pettersson

\footnotetext{
Received December 6, 2010

Accepted April 23, 2011.

${ }^{1}$ This communication is approved as UAES Journal Paper Number 8273. Peggy Steele, a member of J. L. Steele's family, is employed by Danisco Inc. (Copenhagen, Denmark), a supplier of bacterial cultures to the food industry.

${ }^{2}$ Corresponding author: jeff.broadbent@usu.edu
}

and Sjöström, 1975; Bartels et al., 1987a,b; Ardö and Pettersson, 1988; Drake et al., 1996). Moreover, milk fermented with certain $L b$. helveticus strains has been shown to become enriched with antihypertensive and immunomodulatory bioactive peptides (Laffineur et al., 1996; LeBlanc et al., 2002; Hayes et al., 2007b; Gobbetti et al., 2010). Although Lb. helveticus is commonly associated with milk environments, this species has also been recovered from whisky fermentations (Cachat and Priest 2005; Naser et al. 2006) and, more sporadically, from the human reproductive or gastrointestinal tracts (Anukam et al. 2006; Stoyancheva et al. 2006; Vitali et al. 2010).

Lactobacillus helveticus is auxotrophic for several AA (Kandler and Weiss, 1986; Christensen and Steele, 2003; Christiansen et al., 2008), so rapid growth in milk or other environments that contain low levels of free AA relies on a complex proteolytic enzyme system whose collective function involves the procurement of essential AA needed for growth (Christensen et al., 1999). Detailed analysis of the proteolytic enzyme system in dairy LAB, most notably Lactococcus lactis and Lb. helveticus, has shown that enzymes involved in the release of essential AA from large proteins such as $\mathrm{CN}$ can be loosely divided into 3 major categories: (1) an extracellular, cell envelope-associated proteinase (CEP) that hydrolyzes CN into oligopeptides; (2) specialized transport systems to take up those oligopeptides, as well as di- and tripeptides, and free AA that may be present in the medium; and (3) intracellular endopeptidases and exopeptidases, including many that are specific for proline-containing peptides, which degrade internalized peptides into di- and oligopeptides and free AA (Christensen et al., 1999; Savijoki et al., 2006).

Although the biological role of the proteolytic enzyme system is directed toward cellular growth needs, the actions of these enzymes in cheese and fermented foods has important practical consequences on the sensory, functional (stretch, melt), and bioactive attributes 
of these products (Oommen et al., 2002; Broadbent and Steele, 2007; Hayes et al., 2007a). Moreover, subsequent conversion of some free AA into volatile and nonvolatile compounds by LAB in cheese is believed to represent the rate-limiting step in the development of mature flavor and aroma (Yvon and Rijnen, 2001; Ardö, 2006). For these reasons, the relationship between proteolytic enzyme activity and dairy foods quality has been a focal point of dairy research for decades.

Studies in the field have shown a variety of LAB may contribute to these reactions and properties (Fox, 1989; Gobbetti et al., 2002; Azarnia et al., 2006; Cogan et al., 2007; Hayes et al., 2007b) and that the proteolytic enzymes found in these cells are, for the most part, distributed across all dairy LAB (Christensen et al., 1999; Savijoki et al., 2006; Liu et al., 2010). However, broad differences in specificity and relative activity of individual enzymes exist, with lactobacilli generally showing higher proteolytic activity than other types of LAB (Sasaki et al., 1995; Gilbert et al., 1997; Weimer et al., 1997; Laan et al., 1998). Lactobacilli also possess a greater number and diversity of genes for proteinases and peptidases. Only lactobacilli, for example, have been found to possess more than one gene for CEP, and these bacteria also show greater redundancy in the number of genes for di- and tripeptidases and for endopeptidase PepO (Pederson et al., 1999; Sridhar et al., 2005; Liu et al., 2010). Lactobacilli also have genes for several endo- and aminopeptidases, including oligoendopeptidases PepE and PepG, proline iminopeptidase PepI, prolyl aminopeptidase PepL, and prolinase PepR, which have not been found in Lc. lactis or Streptococcus thermophilus (Christensen et al., 1999; Savijoki et al., 2006; Liu et al., 2010).

Among lactobacilli, Lb. helveticus is especially recognized for its active protease and peptidase activities toward milk proteins (Gilbert et al., 1997; Christensen et al., 1999; Matar et al., 2001; Savijoki et al., 2006), and the most thoroughly characterized proteolytic enzyme system in $L b$. helveticus belongs to strain CNRZ 32 (reviewed by Christensen et al., 1999; plus Pederson et al., 1999; Chen et al., 2003; Christensen and Steele 2003; Sridhar et al., 2005; Smeianov et al., 2007). Lactobacillus helveticus CNRZ 32 is an industrial bacterium that decreases bitterness and accelerates cheese flavor development, and has also been shown to be capable of producing anti-hypertensive peptides in milk (Bartels et al., 1987a,b; Christensen et al., 1999; Savijoki et al., 2006; Kilpi et al., 2007). Because these attributes are strain-specific (Laffineur et al., 1996; Gummalla and Broadbent 1999; Deutsch et al., 2000; Klein et al., 2001; Jensen et al., 2009; Jensen and Ardö, 2010), we performed comparative genome hybridizations (CGH) to a CNRZ 32 microarray to explore the distribution of genes involved in proteolysis and AA catabolism among a bank of $L b$. helveticus strains isolated from different sources.

\section{MATERIALS AND METHODS}

\section{Comparative Genome Hybridizations}

Lactobacillus helveticus strains used in this study for CGH were selected to provide broad representation of the ecological and industrial diversity in this species (Table 1). Industrial strains and whiskey isolates were obtained from culture collections at Utah State University, the University of Wisconsin-Madison, the University of Copenhagen, the Centre National de Recherche Zootechnique, and the Institut Rosell. The UPR natural starter strains were isolated at the University of Parma from Grana Padano, Provolone, or Parmigiano Reggiano cheese whey, or fresh Parmigiano Reggiano curd (Table 1), essentially as described by Gatti et al. (2003).

Stock cultures were maintained at $-80^{\circ} \mathrm{C}$ in de Man, Rogosa, Sharpe (MRS) broth (Difco Laboratories, Detroit, MI) with $20 \%$ (vol/vol) glycerol. Working cultures were prepared from stock cultures by 2 successive transfers (1\% inocula) in MRS broth at $37^{\circ} \mathrm{C}$ for 16 to $18 \mathrm{~h}$. Comparative genome hybridization experiments were performed using an Affymetrix (Affymetrix Inc., Santa Clara, CA) custom microarray designed to include eleven 24-mer probes for each of 2,387 predicted coding sequences (CDS, including pseudogenes) in the Lb. helveticus CNRZ 32 genome, as well as all nonredundant CDS in the Lactobacillus casei ATCC 334 genome (Cai et al., 2009). The only CDS not included in the microarray design were duplicate copies of rRNA and transposase-encoding genes found in each species.

Genomic DNA for CGH was extracted from each strain using a MasterPure Gram-Positive DNA Purification Kit (Epicentre Biotechnologies, Madison, WI). Five micrograms of genomic DNA was fragmented and labeled according to instructions for labeling mRNA for antisense prokaryotic arrays (Affymetrix Inc.). Reactions for hybridization contained $1 \mu \mathrm{g}$ of labeled DNA and were performed using the fully automated components (Fluidics Station 450 and GeneChip Scanner 3000) of an Affymetrix GeneChip System operated by staff in the Utah State University Center for Integrated Biosystems (Logan, UT). Statistical analysis of microarray data was done using $\mathrm{R}$ software (http:// www.r-project.org). To screen for artifacts that pose quality problems, the array images were reduced to intensity values for each probe and evaluated for quality using the AffyPLM program (Bolstad et al., 2005) for Bioconductor (http://www.bioconductor.org). Arrays that met acceptable quality control criteria established 
Table 1. Lactobacillus helveticus strains used in comparative genome hybridizations

\begin{tabular}{|c|c|}
\hline Strain & Origin (source or reference) \\
\hline R0052 & Industrial dairy starter culture (Naser et al., 2006) \\
\hline ATCC 15009 & Swiss cheese (type strain, also called DSM 20075; American Type Culture Collection, Manassas, VA) \\
\hline CNRZ 32-1997 & Archival CNRZ 32 sample stored at $-80^{\circ} \mathrm{C}$ in 1997 (University of Copenhagen, Denmark) \\
\hline CNRZ 303 & Industrial dairy starter culture (Centre National de Recherche Zootechnique, Jouy-en-Josas, France) \\
\hline LHC2 & Industrial dairy starter culture (University of Wisconsin, Madison) \\
\hline MI 2275 & Industrial dairy starter culture (Jensen et al., 2009) \\
\hline MI 2359 & Kadett cheese (Jensen et al., 2009) \\
\hline R150 & Industrial dairy starter culture (Utah State University, Logan) \\
\hline R211 & Industrial strain used for production of bioactive dairy foods (Leclerc et al., 2002) \\
\hline $\mathrm{R} 220$ & Industrial dairy starter culture (Utah State University, Logan) \\
\hline R389 & Industrial strain used for production of bioactive dairy foods (Matar et al., 2001) \\
\hline L89 & Proteinase-deficient mutant of strain R389 (Matar et al., 2001) \\
\hline UPR6 & Fresh Parmigiano Reggiano curd (this study) \\
\hline UPR8 & Fresh Parmigiano Reggiano curd (this study) \\
\hline UPR9 & Fresh Parmigiano Reggiano curd (this study) \\
\hline UPR10 & Fresh Parmigiano Reggiano curd (this study) \\
\hline UPR11 & Natural whey starter, Parmigiano Reggiano cheese (this study) \\
\hline UPR12 & Natural whey starter, Parmigiano Reggiano cheese (this study) \\
\hline UPR13 & Natural whey starter, Provolone cheese (this study) \\
\hline UPR14 & Natural whey starter, Parmigiano Reggiano cheese (this study) \\
\hline UPR15 & Natural whey starter, Parmigiano Reggiano cheese (this study) \\
\hline UPR16 & Natural whey starter, Grana Padano cheese (this study) \\
\hline UPR17 & Natural whey starter, Grana Padano cheese (this study) \\
\hline UPR18 & Natural whey starter, Provolone cheese (this study) \\
\hline UPR19 & Natural whey starter, Provolone cheese (this study) \\
\hline UPR20 & Natural whey starter, Provolone cheese (this study) \\
\hline
\end{tabular}

by AffyPLM were used for further analysis. Array preprocessing (background correction, normalization, and summarization) was performed using the Robust Multi-array Average method (Bolstad et al., 2003) using Bioconductor. Cutoff values for presence/absence determination in $L b$. helveticus strains were selected empirically based on hybridization signal intensity from positive (genomic DNA from Lb. helveticus CNRZ 32) and negative (hybridization of $L b$. casei ATCC 334 genomic DNA) probe controls. Results were clustered and visualized by TIGR MultiExperiment Viewer (TMEV) 4.0 (Saeed et al., 2003), using Euclidean Distance as a distance metric. The Support Tree method of bootstrapping implemented in TMEV was used to test the reliability of the clustering patterns $(1,000$ bootstrap re-samplings).

\section{Distribution of CEP Paralogs Among Lb. helveticus Strains}

Multiplex PCR was used to evaluate the presence and distribution of CEP paralogs prtH, prtH2, prtH3, and $\operatorname{prtH}_{4}$ in 9 of the $L b$. helveticus strains analyzed by CGH (CNRZ 32, R0052, ATCC 15009, R211, R389, L89, LMG 22464, Y10, and M4), 13 additional $L b$. helveticus strains (ATCC 521, ITG LH1, ITG LH43, ITG LH44, ITG LH55, ITG LH56, ITG LH68, ITG LH77, R204, R234, R235, R247, and R338), 3 strains of Lactobacillus acidophilus (NCFM, R240, and R269), and in Lactobacillus gallinarum ATCC 53673.

The strains were propagated and DNA isolated essentially as described for CGH experiments, then 2 different multiplex PCR reactions were performed, one for prtH and prtH3, and the other for prtH2 and prtH4. Both were carried out in $25-\mu \mathrm{L}$ reactions that contained $1 \mathrm{X}$ polymerase buffer, $0.2 \mathrm{~m} M$ each of deoxyribonucleotide triphosphate (dNTP), $1 \mathrm{pmol} / \mu \mathrm{L}$ of each primer (Table 2), $100 \mathrm{ng}$ of template DNA, and $0.05 \mathrm{U} / \mu \mathrm{L}$ of Taq DNA polymerase. One sample (negative control) contained water instead of template DNA. The PCR was initiated by template denaturation at $94^{\circ} \mathrm{C}$ for $5 \mathrm{~min}$, followed by 30 cycles of heating to $94^{\circ} \mathrm{C}$ for $30 \mathrm{~s}$, annealing at $54^{\circ} \mathrm{C}$ for $30 \mathrm{~s}$, extension at 
Table 2. Primers used in multiplex PCR reactions to detect cell envelope-associated proteinase paralogs in strains of Lactobacillus helveticus $^{1}$

\begin{tabular}{|c|c|c|c|c|}
\hline Multiplex & Gene & $\begin{array}{l}\text { Primer } \\
\text { name }\end{array}$ & Primer sequence $\left(5^{\prime}-3^{\prime}\right)$ & $\begin{array}{l}\text { Amplicon } \\
\text { size (bp) }\end{array}$ \\
\hline $\bar{A}$ & $\begin{array}{l}\text { prtH } \\
\text { prtH3 }\end{array}$ & $\begin{array}{l}\text { prtHf } \\
\text { prtHr } \\
\text { prtH3f } \\
\text { prtH3r }\end{array}$ & $\begin{array}{l}\text { CGGGAATCCTGATATGGAAACTTTAGGTAATC } \\
\text { ATTAAGACTAGCAAAGATTGGAAGATCTGAACTTG } \\
\text { GATGATCAAGCAGATGTAAAACCGGCAGAAG } \\
\text { ATTTACTGAAGAATTAGTCAAATGACCTGTTGTCGG }\end{array}$ & $\begin{array}{r}1,332 \\
357\end{array}$ \\
\hline B & $\begin{array}{l}\text { prtH2 } \\
\text { prtH4 }\end{array}$ & $\begin{array}{l}\text { prtH2f } \\
\text { prtH2r } \\
\text { prtH4f } \\
\text { prtH4r }\end{array}$ & $\begin{array}{l}\text { AAGCAAAGGATGTTGTTCCAAGTAAGCCA } \\
\text { CTCTCTTCCTTCTTACCAGTTGATGATTGAACT } \\
\text { CTGAAGCAGCAACTAATGATCCTGG } \\
\text { TGGATTAGGATCCGTTCTGGTTGTCAG }\end{array}$ & $\begin{array}{l}4,042 \\
3,386\end{array}$ \\
\hline
\end{tabular}

${ }^{1}$ Primers were designed from previously described gene sequences for CNRZ 32 cell envelope-associated proteinase genes prt $H$ (Pederson et al., 1999) and prtH2 (Smeianov et al., 2007), as well as prtH3 and prtH4 (GenBank accession numbers HQ602769 and HQ602770, respectively).

$65^{\circ} \mathrm{C}$ for $3 \mathrm{~min}$, followed by $7 \mathrm{~min}$ at $65^{\circ} \mathrm{C}$, and then samples were chilled to $4^{\circ} \mathrm{C}$. The presence of amplicon in these reactions was confirmed by ethidium bromide staining of DNA after samples $(5 \mu \mathrm{L})$ were separated by electrophoresis in $1 \%$ agarose gels.

\section{Milk Acidifying Activity}

The ability of some strains to acidify milk was investigated by inoculation $(2 \% \mathrm{vol} / \mathrm{vol})$ of fresh overnight culture into $10 \mathrm{~mL}$ of $10 \%$ (wt/vol) reconstituted skim milk powder (Oxoid Ltd., Basingstoke, UK) that had been adjusted to $6.8 \mathrm{pH}$ with $0.1 \mathrm{M} \mathrm{NaOH}$ and sterilized by heating to $110^{\circ} \mathrm{C}$ for $30 \mathrm{~min}$. The cells were incubated at $42^{\circ} \mathrm{C}$ overnight, then inoculated at $1 \%$ (vol/vol) into $50 \mathrm{~mL}$ of reconstituted skim milk and pH measured (Metrohm $654 \mathrm{pH}$ meter; Metrohm Ltd., Herisau, Switzerland) immediately after inoculation and after $24 \mathrm{~h}$ of incubation at $42^{\circ} \mathrm{C}$. Strains that failed to produce more than $1 \mathrm{U}$ of decrease in the milk $\mathrm{pH}$ were designated as slow acid producers.

\section{Growth in Cheese Whey}

The contribution of PrtH in growth of CNRZ 32 in cheese whey was explored using 2 independently isolated $p r t H$ deletion mutants (Pederson et al., 1999). The wild-type strain and mutants were collected from $-80^{\circ} \mathrm{C}$ freezer stocks, subcultured twice in $10 \mathrm{~mL}$ of MRS broth, then grown (1\% inoculum) for $16 \mathrm{~h}$ in 10 $\mathrm{mL}$ of UHT-treated milk. Cells were then inoculated at $1 \%$ into duplicate $12-\mathrm{mL}$ samples of filter-sterilized (0.2-um filter; VWR International, Radnor, PA) cheese whey, and the absorbance at $600 \mathrm{~nm}$ measured at hourly intervals to $8 \mathrm{~h}$, then again after $18 \mathrm{~h}$ of growth at $37^{\circ} \mathrm{C}$. At that point, a $1 \%$ inoculum of each culture was transferred into a fresh 12-mL whey sample and growth was monitored in the same manner. Additionally, 1-mL samples were collected from each tube at 0,8 , and 18 $\mathrm{h}$ on both days and plated on MRS agar. Colony enu- meration was performed after $48 \mathrm{~h}$ of incubation in anaerobic jars at $37^{\circ} \mathrm{C}$.

\section{RESULTS AND DISCUSSION}

\section{Conservation of Peptidase Genes}

The Lb. helveticus CNRZ 32 genome encodes numerous proteolytic enzymes involved in procurement of essential AA or housekeeping needs (e.g., protein processing and turnover; reviewed by Christensen et al., 1999; Pederson et al., 1999; Chen et al., 2003; Christensen and Steele 2003; Sridhar et al., 2005; Smeianov et al., 2007). As is shown in Table 3, the former group of enzymes includes 4 CEP paralogs, 7 oligoendopeptidases, 3 general aminopeptidases, 5 proline-specific peptidases, 8 di- or tri-peptidases, and at least 6 other peptidases. Remarkably, CGH experiments revealed that the peptidase genes were almost universally conserved among the disparate cheese, whey, whiskey malt, and commercial cultures selected for this research (Table 1). The only exceptions were 6 strains (UPR1, UPR2, UPR10, UPR11, UPR13, and UPR14) that lacked the oligoendopeptidase gene pepO2, and one strain (UPR15) that did not contain the pepE2 gene.

Although peptidase genes are clearly highly conserved across $L b$. helveticus, several studies have shown that peptidase activity in different strains, including 6 of those tested in this work, can vary considerably (Sasaki et al., 1995; Jensen and Ardö, 2010). Moreover, Soeryapranata et al. (2007) characterized the specificity of the $3 \mathrm{PepO}$ paralogs from $L b$. helveticus WSU 19 , and demonstrated each of these enzymes was not identical to its counterpart in CNRZ 32. Furthermore, CGH does not provide information on whether a gene is functional or contains minor sequence polymorphisms that produce AA substitutions affecting enzyme activity. To explore the latter possibilities, we performed Basic Local Alignment Search Tool (BLAST; http:// blast.ncbi.nlm.nih.gov/Blast.cgi) homology searches 
Table 3. Genes encoding cell envelope-associated proteinases and peptidases in Lactobacillus helveticus CNRZ 32

\begin{tabular}{|c|c|}
\hline General enzyme category ${ }^{1}$ & $\begin{array}{l}\text { Gene name (GenBank } \\
\text { accession number) }\end{array}$ \\
\hline Cell envelope-associated proteinases (EC 3.4.21.96) & $\begin{array}{l}\text { prtH (AAD50643) } \\
\text { prtH2 (DQ826130) } \\
\text { prtH3 (HQ602769) } \\
\text { prtH4 (HQ602770) }\end{array}$ \\
\hline Cell envelope-associated maturation proteins (EC 5.2.1.8) & $\begin{array}{l}\text { prtM (DQ826131) } \\
\text { prtM2 (DQ826132) }\end{array}$ \\
\hline \multicolumn{2}{|l|}{ Oligoendopeptidases } \\
\hline Thiol-dependent endopeptidase E (EC 3.4.22.-) & $\begin{array}{l}\text { pepE }(\mathrm{U} 77050) \\
\text { pepE2 (AAQ72431) }\end{array}$ \\
\hline Oligoendopeptidases F and O (EC 3.4.24.-) & $\begin{array}{l}\text { pepF (AY365129) } \\
\text { рерО (AF019410) } \\
\text { pepO2 (DQ826126) } \\
\text { рерO3 (AY365128) }\end{array}$ \\
\hline O-sialoglycoprotein endopeptidase (EC 3.4.24.57) & gср (DQ826107) \\
\hline General aminopeptidases C (EC 3.4.22.40) and N (EC 3.4.11.15) & $\begin{array}{l}\text { рерCE (JF811429) } \\
\text { pepC }\left(\mathrm{HQ602766)^{2 }}\right. \\
\operatorname{pepN}(\mathrm{U} 08224)\end{array}$ \\
\hline \multicolumn{2}{|l|}{ Proline-specific peptidases } \\
\hline X-prolyl diaminopeptidase (EC 3.4.14.11) & pepX $(\mathrm{U} 22900)$ \\
\hline Proline iminopeptidases (EC 3.4.11.5) & $\begin{array}{l}\text { pepI (DQ826125) } \\
\text { pepR (U05214) }\end{array}$ \\
\hline Prolidase (EC 3.4.11.9) & $\begin{array}{l}\text { pepQ (AF012084) } \\
\text { pepQ2 (DQ826127) }\end{array}$ \\
\hline \multicolumn{2}{|l|}{ Di- and Tripeptidases } \\
\hline Dipeptidase A (EC 3.4.13.--) & $\begin{array}{l}\text { pepD (U34257) } \\
\text { pepD2 (DQ826122) } \\
\text { pepD3 (DQ826123) } \\
\text { pepD4 }(\mathrm{DQ826124)} \\
\text { pepD5 (HQ602767) }\end{array}$ \\
\hline Xaa-His dipeptidase (EC 3.4.13.3) & pep $V(\mathrm{AF} 012085)$ \\
\hline Tripeptidase T (EC 3.4.11.4) & $\begin{array}{l}\text { рерT (DQ826128) } \\
\text { рер T2 (DQ826129) }\end{array}$ \\
\hline \multicolumn{2}{|l|}{ Other enzymes } \\
\hline Glutamyl aminopeptidase (EC 3.4.11.7) & рерA (DQ826138) \\
\hline Methionine aminopeptidase (EC 3.4.11.8) & map (DQ826118) \\
\hline Pyrrolidone carboxyl peptidase (EC 3.4.19.3) & рср (DQ826121) \\
\hline SprT-like metallopeptidase (EC 3.4.24.-) & $\operatorname{spr} T$ (HQ602765) \\
\hline M16 family metallopeptidase (EC 3.4.-.--) & hyp prt2 (DQ826112) \\
\hline Membrane alanine aminopeptidase (EC3.4.11.2) & рерM1 (HQ602768) \\
\hline
\end{tabular}

${ }^{1} \mathrm{EC}=$ Enzyme Commission [number].

${ }^{2}$ Predicted pseudogene in Lb. helveticus CNRZ 32.

with the predicted protein sequences for 21 CNRZ 32 peptidases, plus 2 peptidases from DPC 4571 that occur as pseudogenes in CNRZ 32. As expected, AA sequence homology was generally very high over the full length of each protein, but perfect matches were uncommon and nonsense mutations (which created pseudogenes) were present in some strains (Table 4). As a whole, these reports show that even though the peptidase gene content of Lb. helveticus strains is identical, strain heterogeneity may be observed due to loss of gene function or sequence polymorphisms that affect the specificity or relative activity of individual peptidase enzymes.

\section{Heterogeneity in the Distribution of CEP Paralogs}

The 4 CEP genes found in Lb. helveticus CNRZ 32 are predicted to encode proteins that range in size from
1,642 to 1,843 AA for PrtH3 and PrtH, respectively, and share 29 to $70 \%$ AA identity over most of their length (Table 5). We tested a total of $51 \mathrm{Lb}$. helveticus for the presence of each CEP paralog by CGH (36 strains, plus 2 archival samples of CNRZ 32) or multiplex PCR (22 strains, including 9 also tested by CGH, plus 3 strains of Lb. acidophilus and one Lb. gallinarum). Data for strain DPC 4571 was derived from the published genome sequence for that strain (Callanan et al., 2008). Complete agreement between results was found for the 9 strains tested by both methods (Figure 1), and no PCR amplicons were detected after multiplex PCR with template DNA from Lb. acidophilus or Lb. gallinarum strains (Figure 2).

In contrast to the highly conserved peptidases, we found distribution of CEP genes differed widely among $L b$. helveticus strains (Figures 1, and 2). Six of the 
Table 4. Amino acid sequence homology among selected peptidases in different strains of Lactobacillus helveticus ${ }^{1}$

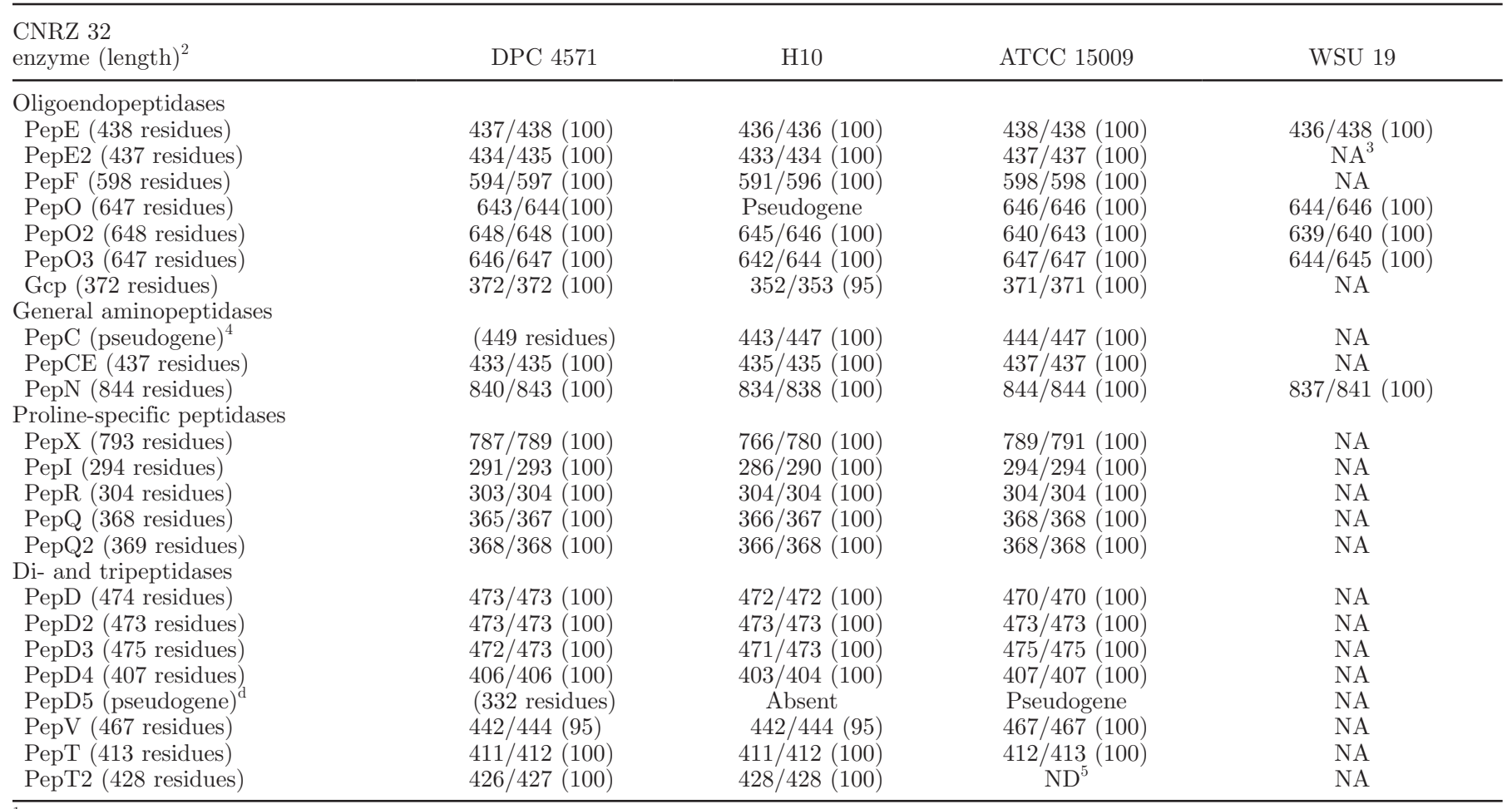

${ }^{1}$ Identical AA/similar AA (\% query coverage).

${ }^{2}$ Predicted from coding sequence.

${ }^{3}$ Gene sequence not publicly available.

${ }^{4}$ Predicted protein sequence from DPC 4571 ortholog used for homology comparisons.

${ }^{5}$ Not detected in draft (incomplete) ATCC 15009 genome, but CGH data indicate the gene is present.

$51(12 \%)$ Lb. helveticus strains (including CNRZ 32) contained all $4 \mathrm{CEP}$ paralogs. An additional 4 strains contained 3 paralogs, whereas 21 strains had genes for 2 CEP. Thus, over $60 \%$ of $L b$. helveticus strains tested contained more than one gene encoding CEP. Only one strain, UPR13, lacked any detectable CEP gene (Figure 1). It is important to note, however, that the methods used in this study can only detect paralogs found in CNRZ 32, so the UPR13 genome could encode an additional and unrelated CEP. The work of Genay et al. (2009) provides evidence to support the latter possibility, as those authors isolated DNA fragments from $L b$. helveticus ROSELL 5088 that appear to encode a CEP enzyme whose sequence was similar to, but not identical with, PrtH. Very recently, the complete coding sequence for this new enzyme was identified in the genome sequence for Lb. helveticus H10 (Zhao et al., 2011). This new gene is predicted to encode a 2,011 residue-long pre-pro-cell-envelope proteinase with $67 \%$ identity and $80 \%$ AA similarity to PrtH, and includes a C-terminal anchor region with homology to S-layer proteins. However, the nucleotide sequence for

Table 5. Amino acid homology among the cell envelope-associated proteinase paralogs found in Lactobacillus helveticus CNRZ $32^{1}$

\begin{tabular}{|c|c|c|c|c|c|c|}
\hline Enzyme (length) ${ }^{2}$ & PrtH & PrtH2 & PrtH3 & La PrtP & $\mathrm{Lj}$ PrtP & Lu PrtP \\
\hline PrtH2 (1,786 residues) & $34 / 50(69)$ & - & & $61 / 75(88)$ & $29 / 47(47)$ & $55 / 70(88)$ \\
\hline PrtH3 (1,642 residues) & $32 / 48(60)$ & $58 / 69(100)$ & - & $59 / 72(98)$ & $32 / 51(50)$ & $53 / 68(98)$ \\
\hline
\end{tabular}

${ }^{1}$ Percent AA identity/percent similarity (\% query coverage). Cell envelope-associated proteinases from Lactobacillus acidophilus NCFM (La PrtP; 1,627 residues), Lactobacillus johnsonii NCC 533 (Lj PrtP; 2,209 residues), and Lactobacillus ultunensis DSM 16047 (Lu PrtP; 1,663 residues) are included for evolutionary reference. GenBank accession numbers for the latter enzymes are AAV43331, AAS09785, and EEJ72368, respectively. Bold font indicates closest taxonomic relative.

${ }^{2}$ Predicted number of AA in nascent pre-pro-protein. 


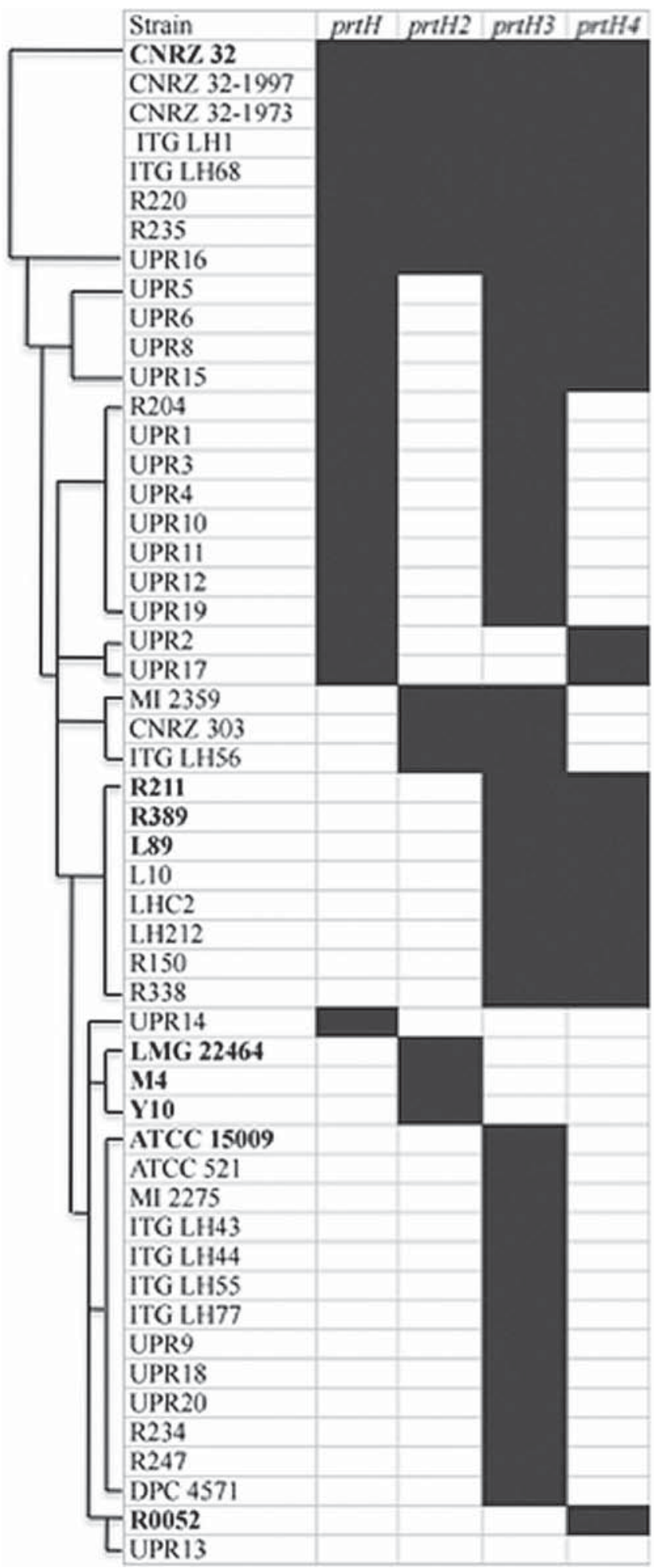

Figure 1. Distribution of Lactobacillus helveticus CNRZ 32 genes associated with cell envelope-associated proteinases among other strains of $L b$. helveticus as determined by comparative genome hybridization $(\mathrm{CGH})$ or multiplex PCR. The presence (gray) or absence (white) of individual genes in different $L b$. helveticus strains is indicated by the fill color. Strains tested by both CGH and multiplex PCR methods are highlighted in bold font. the H10 proteinase lacks any measurable homology to the genome sequence data for strains CNRZ 32 and DPC 4571, or to the draft sequence for ATCC 15009. Because the ability of LAB to rapidly acidify milk requires CEP activity (for reviews, see Kunji et al., 1996; Siezen, 1999), we investigated this attribute in UPR13. Results showed that it reduced milk pH by only $0.9 \mathrm{pH}$ unit after $24 \mathrm{~h}$ of incubation at $42^{\circ} \mathrm{C}$, which indicates that UPR13 does not possess any functional gene for CEP.

The CGH and multiplex PCR approaches used in this work also cannot determine whether a gene is functional. Use of either technique with strain DPC 4571, for example, would be predicted to reveal this strain contains only prtH3 (Figure 1). However, the genome sequence for DPC 4571 (Callanan et al., 2008) reveals the prtH3 CDS contains a nonsense mutation, and the bacterium displays a proteinase-negative phenotype (P. Ross, Teagasc, Moorepark, Ireland, personal communication). Mutations are also likely to be present in the prtH3 and prtH4 CDS of strain L89, as this bacterium is also reported to show a proteinase-negative phenotype (Matar et al., 2001).

As was recently reported by Genay et al. (2009), the distribution of CEP paralogs among $L b$. helveticus strains also was non-uniform. The most abundant paralog was prtH3, which was carried by over $80 \%$ of strains tested. Altogether, prtH3 was detected in all but 2 of the strains that contained more than one gene for CEP, and in 13 of 19 strains found to carry only one CEP paralog (Figure 1). Genes for prtH and prtH4 were also relatively common; each was detected in 21 of 49 distinct strains tested (total excluding the 2 archival samples of CNRZ 32), almost always in combination with other $\mathrm{CEP}$ genes. Interestingly, prt $H$ was especially common among the 19 Lb. helveticus UPR strains isolated from Italian cheese whey or fresh curd (Table 1 and Figure 1). Fifteen (79\%) of the UPR strains contained prtH, and this group represented $71 \%$ of all strains found to contain this paralog. Pederson and coworkers (1999) found prtH inactivation in CNRZ 32 did not affect its rates of acidification or growth in milk, but the disproportionate prevalence of $p r t H$ in $L b$. helveticus collected from Italian cheese whey raised new questions about the contribution this enzyme may provide to cells growing in whey. To explore this question, we compared growth of CNRZ 32 wild-type cells to that for 2 independently isolated $p r t H$ deletion mutants (Pederson et al., 1999) in cheese whey. However, results showed $p r t H$ inactivation had no effect on growth rate of CNRZ 32 in cheese whey (data not shown).

Finally, prtH2 was detected in less than $25 \%$ of $L b$. helveticus strains tested, and like $\mathrm{prtH}_{\mathrm{H}}$ and $\mathrm{prtH}_{4}$, it usually occurred in strains that carried other CEP 
A)

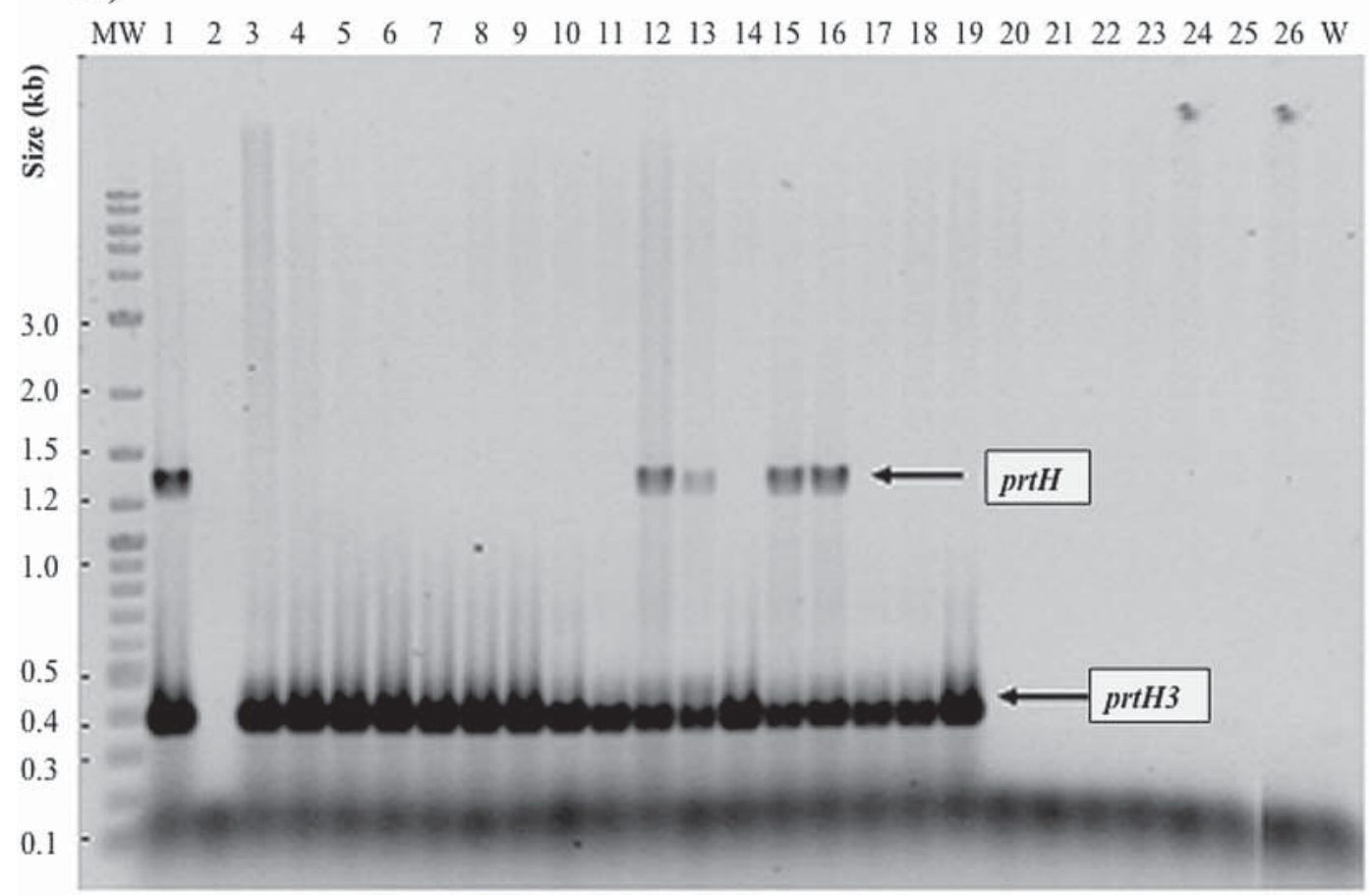

B)

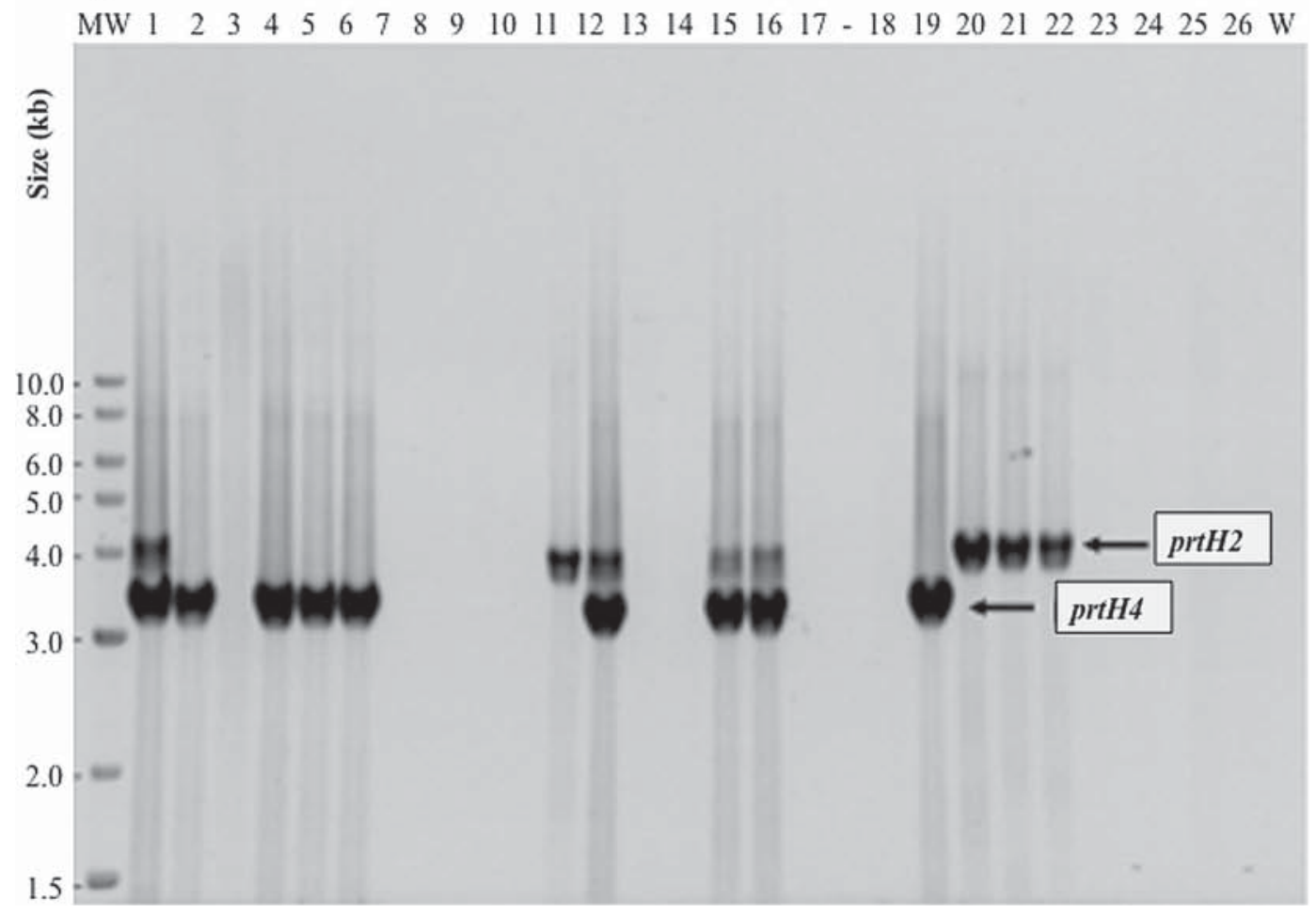

Figure 2. Agarose gel electrophoresis of amplicons derived from lactobacilli after multiplex PCR with prtH and prtH3- (panel A) or prtH2 and prtH4-specific primers (panel B). Samples present in each gel include lane 1 to 22, Lactobacillus helveticus strains CNRZ 32, R0052, ATCC 15009, R211, R0389, L89, ITG LH44, ITG LH77, ITG LH43, ITG LH55, ITG LH56, ITG LH68, R204, R234, ITG LH1, R235, R247, ATCC 521, R338, LMG 22464, M4, and Y10, respectively; lanes 23 to 25, Lactobacillus acidophilus strains NCFM, R240, and R269, respectively; and lane 26, Lactobacillus gallinarum ATCC 53673. MW denotes a DNA fragment size standard run in the left lane of each gel, and W denotes the negative control that contained water instead of template DNA. 
CNRZ 32:

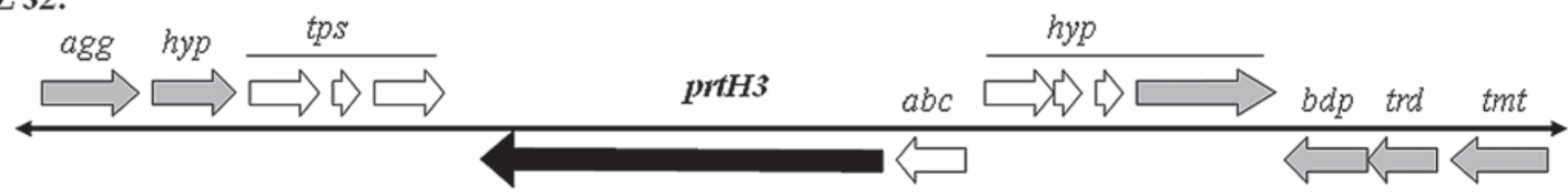

DPC 4571:

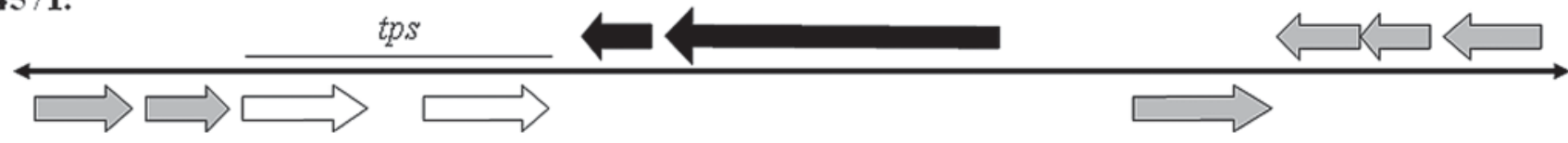

Figure 3. Organization of the prtH3 locus in Lactobacillus helveticus CNRZ 32 and DPC 4571 . The prtH3 gene is indicated by black fill, and flanking genes common to both strains appear in gray directly above one another. The nonsense mutation present in DPC 4571 is reflected by the split prtH3 coding sequence. Abbreviations for predicted gene functions: agg, aggregation-promoting protein; hyp, hypothetical protein; tps, transposase; prtH3, cell envelope-associated proteinase PrtH3; abc, ABC transporter, permease protein; $b d p$, tRNA binding domain protein; trd, thioredoxin; tmt, transfer RNA (tRNA) methyltransferase.

genes. Curiously, the only exceptions to this observation involved 3 strains, LMG 22464, M4, and Y10, which were originally isolated from whiskey fermentations (Table 1 and Figure 1). This observation suggests PrtH2 may contribute to growth of Lb. helveticus on plant-derived proteins, but additional experiments will be needed to test that hypothesis.

Our results related to the distribution of CEP para$\operatorname{logs}$ among $L b$. helveticus conflict with a recent report by Genay et al. (2009), who concluded prtH2 was more prevalent than prtH. The CGH and multiplex PCR data presented here clearly show the most common CEP gene is prtH3, and prtH2 is actually the least abundant paralog (Figures 1 and 2). The basis for this discrepancy is clear; Genay et al. (2009) did not have access to the prtH3 or prtH4 sequences, and opted to annotate the CEP pseudogene found in the sequenced bacterium DPC 4571 (and homologous sequences they detected by PCR in other strains) as a new prtH2 allele rather than $\operatorname{prtH3}$, despite the fact it showed only about $60 \%$ nucleotide and AA sequence identity to prtH2. However, alleles are partly defined by having a common location in the genome, whereas paralogous genes occur at different sites and may display a higher level of sequence divergence due to mutation or selection away from a common ancestral gene. The prtH3 loci in CNRZ 32 and DPC 4571 are 99\% identical at the nucleotide sequence level, and have shared flanking sequences (Figure 3). Thus, prtH3 should be viewed as a paralog, and not an allele, of prtH2 (which, of course, occurs at a different location in the CNRZ 32 genome).

The existence of 4 distinct CEP genes in CNRZ 32 poses interesting questions about the manner in which they may have been acquired. The BLAST homology searches against the protein and nucleotide databases reveal that PrtH is most similar to the CEP found in Lactobacillus johnsonii, an intestinal species (Table 5).
The PrtH2 and PrtH3 enzymes produced the highest homology scores against one another and with the PrtP enzyme from $L b$. acidophilus, a species that also occurs in the intestinal tract. Although AA homology of both paralogs to PrtP was similar (Table 5), the alignment between PrtH3 and PrtP extended over 98\% of the enzyme, whereas that for PrtH2 covered $88 \%$. Finally, PrtH4 showed $92 \%$ identity at the nucleotide level, and $93 \%$ identity (as well as $96 \%$ similarity) at the AA level, over the entire length of the CEP found in Lactobacillus ultunensis, a species found in the human oral cavity and stomach. These findings, coupled with the relative distribution of each paralog in $L b$. helveticus and the close phylogenetic relationship of this species with $L b$. acidophilus, suggest that prtH3 is the ancestral CEP in $L b$. helveticus, and that prtH2 likely arose from duplication of prtH3. Because PrtH and PrtH4 show highest homology to enzymes from other species of lactobacilli, it is likely that these enzymes were independently acquired through horizontal gene transfer.

In some species of LAB, CEP activation requires a maturation protein termed PrtM (Savijoki et al., 2006). Liu et al. (2010) recently surveyed genome sequence data for proteolytic enzymes in 19 species of LAB, and detected a prtM ortholog in only 3 species of lactobacilli: Lb. johnsonii, Lb. casei, and Lactobacillus rhamnosus. We previously identified 2 prtM paralogs, designated prtM and prtM2, in Lb. helveticus CNRZ 32 (Smeianov et al., 2007). These proteins are predicted to be 310 and $306 \mathrm{AA}$ in length, respectively, and display $49 \%$ AA identity and $69 \%$ similarity to one another. The physical location of prtM in CRNZ 32 reflects the typical organization for this gene in LAB (Savijoki et al., 2006); it occurs immediately adjacent to, but in divergent orientation to, the $5^{\prime}$ end of prtH. The prtM2 gene shows similar basic organization to prtH3, except that the 2 CDS are separated by approximately $9 \mathrm{~kb}$, with 
several other CDS in between. As expected, protein homology searches showed that PrtM is most closely related (64\% AA identity and $81 \%$ similarity) to its ortholog in Lb. johnsonii, and presence of this gene was almost exclusively restricted to strains that also contained prtH (Figure 1). The only exceptions were UPR 9 and UPR 13, which may indicate that these strains lost $\operatorname{prtH}$ through a deletion event (a possibility that is supported by the proteinase-negative phenotype of UPR 13) or, alternatively, that UPR9 contains a prtH paralog whose nucleotide sequence differs from that found in CNRZ 32. As has already been noted, evidence to support the latter possibility has been provided by Genay et al. (2009) and Zhao et al. (2011). Like prtH in CNRZ 32, the $5^{\prime}$ end of the CEP gene in Lb. helveticus H10 is immediately adjacent to a prsA paralog (with $67 \%$ identity and $82 \%$ similarity to the CNRZ 32 PrtM maturase) that lies in divergent orientation. Interestingly, the coding sequences for the maturase also lacks any measurable nucleotide homology to the CNRZ 32 genome. The discovery of new prtH and prt $M$ paralogs reinforces the view that the rich diversity of cell envelope proteinases in Lb. helveticus is unparalleled among other LAB, and supports our hypothesis that different proteinase combinations have a prominent role in the industrial functionality of this species.

In contrast to prtM, prtM2 was detected by CGH in all $L b$. helveticus strains tested, and BLAST searches revealed the presence of highly conserved $(>90 \%$ AA identity) orthologs in Lb. helveticus DPC 4571, Lb. acidophilus NCFM, and Lb. ultunensis DSM 16047. In the latter strains, this gene is annotated as prsA, which encodes a lipoprotein foldase that (like PrtM) is a member of the peptidyl-prolyl cis/trans isomerase superfamily [Enzyme Commission (EC) number 5.2.1.8] involved in enzyme secretion and activation in gram-positive bacteria (Kontinen et al., 1991; Jacobs et al., 1993; Hermans et al., 2006). Three families of peptidyl-prolyl cis/trans isomerases, termed cyclophilins, FK506-binding proteins, and parvulins, are found in bacteria and higher cells (Rahfeld et al., 1994; Nagradova, 2007). In addition to prtM and prtM2, genes predicted to encode cyclophilin- and FKBP-type peptidyl-prolyl cis/trans isomerases are also present in CNRZ 32, and the latter genes were also detected by $\mathrm{CGH}$ in all $L b$. helveticus strains tested.

Various orthologs of LAB PrtM proteins show 30 to $34 \%$ AA identity to the Bacillus subtilis PrsA protein, and both appear to belong to the parvulin family of peptidyl-prolyl cis/trans isomerases (Rahfeld et al., 1994). More importantly, Jacobs et al. (1993) showed PrsA had a crucial role in the proper folding of different exoproteins, including the serine proteinase subtilisin. Collectively, these findings strongly suggest that PrtM is required for activation of PrtH, whereas PrtM2 could have a role in folding and activation of the other CEP paralogs found in Lb. helveticus and related species of lactobacilli.

Phylogenetic analysis of CEP proteins from CNRZ 32 and those from other LAB shows that enzymes from lactobacilli are distributed across 6 distinct clusters (Figure 4). One contains enzymes from the Lactobacillus delbrueckii group, a second holds Lb. helveticus PrtH and the Lb. johnsonii PrtP, the third includes PrtP enzymes of $L b$. casei and Lc. lactis, the fourth includes CNRZ 32 PrtH2, PrtH3, and PrtH4 plus CEP from $L b$. acidophilus NCFM and Lb. ultunensis DSM 16047, the fifth holds the $L b$. rhamnosus PrtR enzyme, and the last includes PrtR-like enzymes from $L b$. casei. Research with the highly related (98\% AA sequence identity) CEP alleles found in Lc. lactis has shown that these enzymes may be differentiated by their relative affinity and specificity for individual CN (Kunji et al., 1996), and that these differences can impart significantly different effects on the peptide profiles and sensory quality of cheese (Broadbent et al., 2002, 2006; Pillidge et al., 2003). Enzymes from Lb. helveticus and other lactobacilli can also differ in their relative affinity and specificity toward CN (Kunji et al., 1996; Oberg et al., 2002; Jensen et al., 2009), and research suggests these differences can influence the functional properties of cheese (Oommen et al., 2002). Thus, the rich diversity of CEP enzymes found in Lb. helveticus has enormous implications for the applications of these cells in the manufacture of cheese and bioactive foods. For example, the basis for strain-to-strain variability in production of bioactive peptides by $L b$. helveticus is unknown, but release of these peptides obviously requires hydrolysis of intact CN and CEP is the only proteolytic enzyme in LAB that efficiently catalyzes this reaction. It is, therefore, not surprising that CEP activity in $L b$. helveticus has been implicated in the release of $\mathrm{ACE}$ inhibitory, immunomodulatory, and antimicrobial peptides from milk (Yamamoto et al., 1994; Matar et al., 2001; Minervini et al., 2003; de Moreno de LeBlanc et al., 2005). Results from this study indicate that CEP gene content may be a primary factor in determining the functionality of $L b$. helveticus strains in cheese and bioactive milks.

\section{Genes Associated with Amino Acid Metabolism}

As a species, $L b$. helveticus has more extensive AA requirements than most LAB (Kandler and Weiss, 1986), and previous analysis of the AA requirements for Lb. helveticus CNRZ 32 demonstrated this strain was auxotrophic for 14 AA (Christensen and Steele, 2003; Christiansen et al., 2008). Because AA breakdown by 


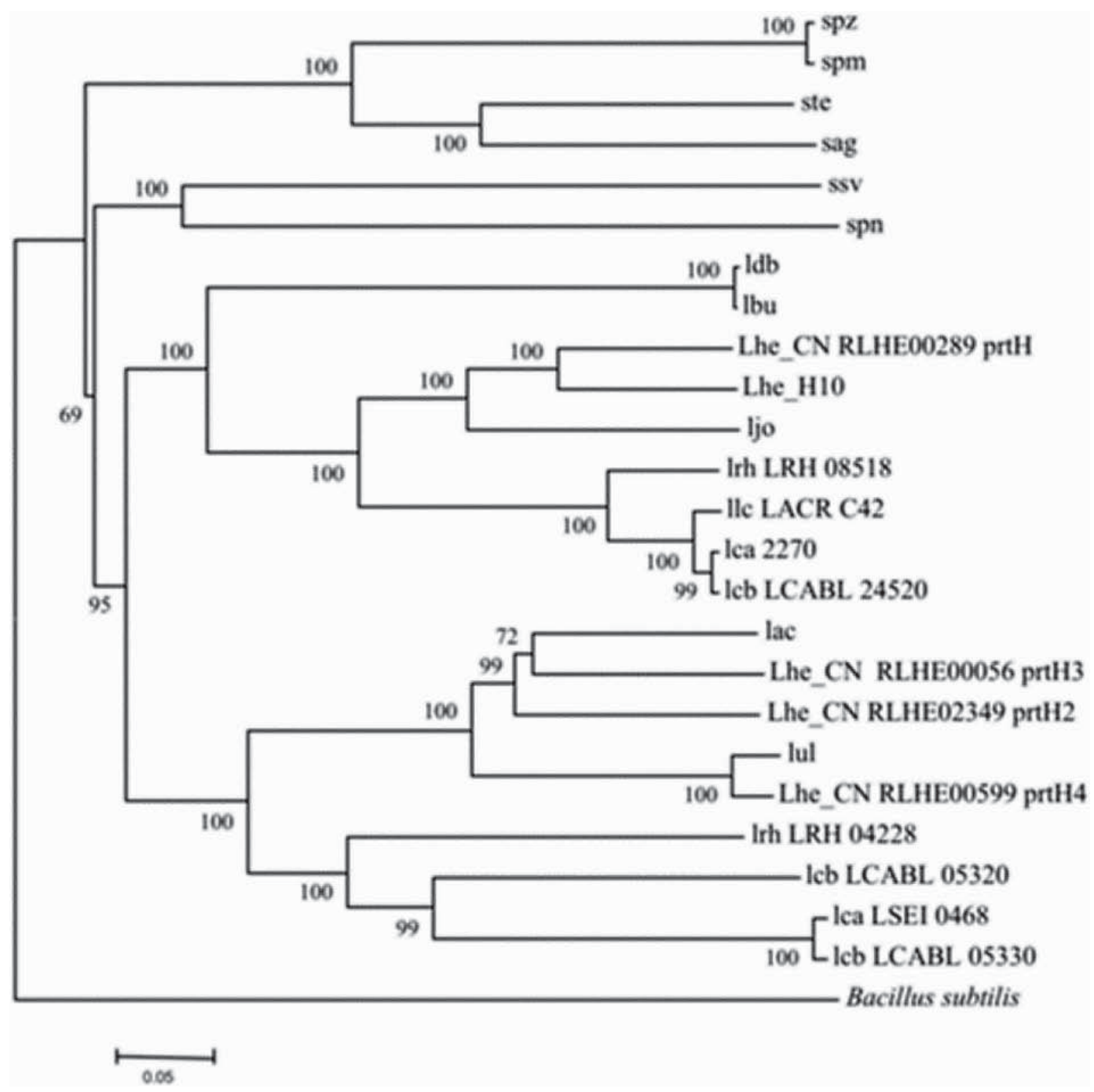

Figure 4. Minimum evolution phylogenetic trees for lactocepin from 17 LAB strains. Bacillus subtilis is used as an outgroup. Bootstrap values on the bifurcating branches are based on 1,000 random bootstrap replicates for the consensus tree. Gene ID is given for strains with more than one homolog. Strain code: lac, Lactobacillus acidophilus NCFM; lbu, Lactobacillus delbrueckii ATCC BAA-365; lca, Lactobacillus casei ATCC 334; lcb, Lb. casei BL23; ldb, Lb. delbrueckii ATCC 11842; lhe_CN, Lactobacillus helveticus CNRZ32; lhe_H10, Lb. helveticus H10; ljo, Lactobacillus johnsonii NCC 533; lrh, Lactobacillus rhamnosus HN001; llc, Lactococcus lactis ssp. cremoris SK11; lul, Lactobacillus ultunensis DSM 16047; sag, Streptococcus agalactiae 2603 (serotype V); spn, Streptococcus pneumoniae TIGR4; spz, Streptococcus pyogenes MGAS5005 (serotype M1); spm, Streptococcus pyogenes MGAS8232 (serotype M18); ssv, Streptococcus suis 98HAH33; and ste, Streptococcus thermophilus LMD-9.

LAB often involves the reversible action of enzymes involved in anabolic pathways (Yvon and Rijnen, 2001; Ardö, 2006), we used CGH to investigate the distribution of CNRZ 32 genes for AA biosynthesis and metabolism among our bank of $L b$. helveticus strains. Those experiments revealed that genes involved in AA metabolism were highly conserved across the species (Figure 5), and most of the observed differences would not be predicted to affect flavor or aroma production in cheese. Nonetheless, 2 noteworthy differences were detected. First, several of the Italian whey isolates did not contain cystathionine- $\beta$-lyase (EC 4.4.1.8), an en- zyme that converts Met into methanethiol (MtSH), a volatile sulfur compound whose production has been associated with desirable cheese flavor and aroma (Dias and Weimer, 1998; Lee et al., 2007). Thus, Lb. helveticus strains lacking this enzyme may have a decreased capacity to produce sulfur-based flavor and aroma in cheese.

A second observation involved the absence of $\operatorname{ser} C$, which encodes phosphoserine transaminase (EC 2.6.1.52), in 8 strains, including all 3 whiskey isolates (Figure 5). In CNRZ 32, serC is adjacent to 3-phosphoglycerate dehydrogenase (serA; EC 1.1.1.95) and 


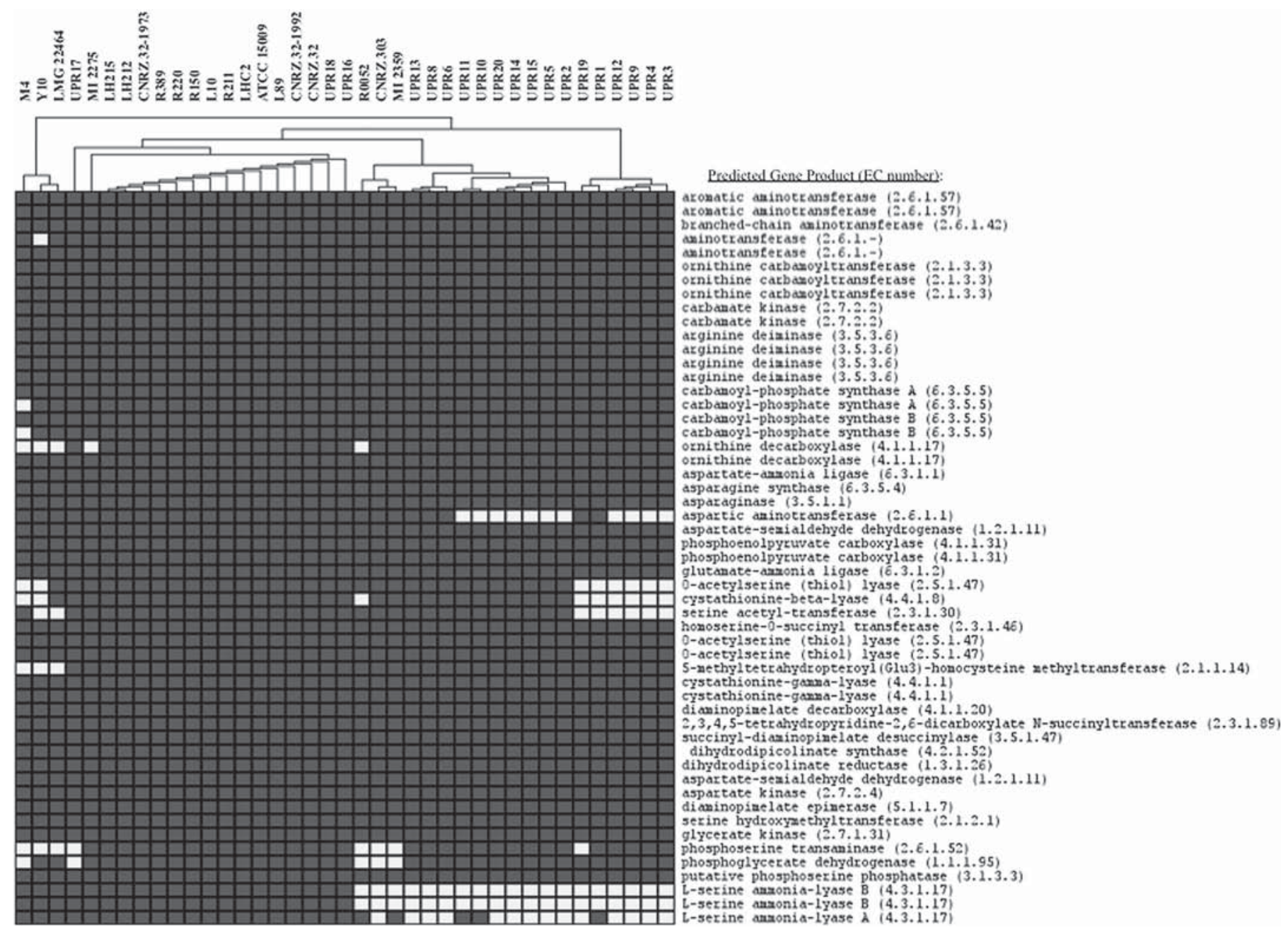

Figure 5. Distribution of Lactobacillus helveticus CNRZ 32 genes associated with amino acid metabolism among other strains of Lb. helveticus as determined by comparative genome hybridization ( $\mathrm{CGH}$ ) alone. The presence (gray) or absence (white) of individual genes in different $L b$. helveticus strains is indicated by the fill color.

phosphoglycerate mutase (pgm; EC 5.4.2.1), and all 3 genes are significantly upregulated during growth of this bacterium in milk (Smeianov et al., 2007). Because expression of other genes involved in Ser biosynthesis was not altered, those authors proposed that SerA, SerC, and Pgm allow Lb. helveticus to derive energy from the phosphoserine residues that are abundant in milk CN. The absence of $\operatorname{ser} C$ in all of the whiskey isolates is consistent with the hypothesis that this pathway may reflect specialization of certain $L b$. helveticus strains to a milk-based environment.

Even though most CNRZ 32 genes for AA biosynthesis and metabolism were conserved in all of the $L b$. helveticus strains tested, previous investigators have shown the activity of these enzymes in different strains (including 6 tested in this study), as well as the levels of aroma compounds they produce, can vary (Klein et al., 2001; Jensen and Ardö, 2010). To explore the molecular basis for this observation, we again performed BLAST homology searches with the predicted protein sequences for 33 CNRZ 32 enzymes involved in AA biosynthesis, as well as 5 enzymes from DPC 4571 or H10 that occur as pseudogenes in CNRZ 32, and 3 enzymes from related lactobacilli that were found to exist as pseudogenes in each of the sequenced strains of Lb. helveticus (Table 6). That analysis confirmed our conclusion from CGH data that some $L b$. helveticus strains lack genes encoding cystathionine- $\beta$-lyase and phosphoserine transaminase. Moreover, it again revealed that although AA sequence homology was typically very high over the full length of each enzyme, perfect sequence matches were uncommon and nonsense mutations had occurred in some strains (Table 6 ). From these data, we conclude the heterogeneity that 
Table 6. Amino acid sequence homology among AA biosynthetic enzymes in different strains of Lactobacillus helveticus ${ }^{1}$

\begin{tabular}{|c|c|c|c|}
\hline CNRZ 32 protein (length) ${ }^{2}$ & DPC 4571 & $\mathrm{H} 10$ & ATCC 15009 \\
\hline Aspartate aminotransferase (388 residues) & $388 / 388(100)$ & $382 / 382(100$ & $388 / 388(100)$ \\
\hline Branched-chain aminotransferase (341 residues) & $338 / 340(100)$ & $338 / 341(100)$ & $341 / 341(100)$ \\
\hline Phosphoserine transaminase (334 residues) & $325 / 325(100)$ & Absent & $\mathrm{ND}^{3}$ \\
\hline Ornithine carbamoyltransferase (pseudogene) ${ }^{4}$ & Pseudogene & Pseudogene & Pseudogene \\
\hline Carbamate kinase (pseudogene) & Pseudogene & Pseudogene & Pseudogene \\
\hline Carbamoyl-phosphate synthase A2 (361 residues) & $354 / 357(100)$ & $355 / 358(100)$ & $361 / 361(100)$ \\
\hline Carbamoyl-phosphate synthase B (1,063 residues) & $1054 / 1057$ (100) & $1052 / 1058(100)$ & $1054 / 1059(100)$ \\
\hline Carbamoyl-phosphate synthase B2 (1,062 residues) & $1060 / 1060(100)$ & $968 / 1020(100)$ & $\mathrm{PG}^{5}$ \\
\hline Ornithine decarboxylase OdcI (701 residues) & $697 / 699(100)$ & $691 / 694(100)$ & ND \\
\hline Ornithine decarboxylase OdiC (698 residues) & $690 / 695(100)$ & $687 / 690(100)$ & ND \\
\hline Aspartate-ammonia ligase (337 residues) & $333 / 336(100)$ & $327 / 334(100)$ & $336 / 336(100)$ \\
\hline Asparagine synthase (649 residues) & $648 / 648(100)$ & $647 / 647(100)$ & $649 / 649(100)$ \\
\hline Cystathionine- $\beta$-lyase (394 residues) & $394 / 394(100)$ & Absent & $394 / 394(100)$ \\
\hline Serine acetyl-transferase (185 residues) & $172 / 172(92)$ & Absent & $185 / 185(100)$ \\
\hline Homoserine- $O$-succinyl transferase (264 residues) & $263 / 264(100)$ & $261 / 263(100)$ & $264 / 264(100)$ \\
\hline$O$-Acetylserine (thiol) lyase (pseudogene) ${ }^{6}$ & (309 residues) & $305 / 307(100)$ & $307 / 309(100)$ \\
\hline $\begin{array}{l}\text { 5-Methyltetrahydropteroyl }\left(\mathrm{Glu}_{3}\right) \text {-homocysteine methyltransferase } \\
\text { (761 residues) }\end{array}$ & $761 / 761(100)$ & $755 / 760(100)$ & $761 / 761(100)$ \\
\hline Cystathionine- $\gamma$-lyase (pseudogene) ${ }^{6}$ & (385 residues) & $381 / 383(100)$ & Pseudogene \\
\hline Diaminopimelate decarboxylase (438 residues) & $434 / 435(100)$ & $433 / 434(100)$ & $438 / 438(100)$ \\
\hline $\begin{array}{l}2,3,4,5 \text {-Tetrahydropyridine- } 2,6 \text {-dicarboxylate } N \text {-succinyltransferase } \\
\text { (236 residues) }\end{array}$ & $236 / 236(100)$ & $236 / 236(100)$ & $236 / 236(100)$ \\
\hline Succinyl-diaminopimelate desuccinylase (384 residues) & $380 / 383(100)$ & $379 / 382(100)$ & $P G$ \\
\hline Dihydrodipicolinate synthase (311 residues) & $309 / 309(100)$ & $308 / 309(100)$ & $311 / 311(100)$ \\
\hline Dihydrodipicolinate reductase (259 residues) & $257 / 257(100)$ & $256 / 256(100)$ & $259 / 259(100)$ \\
\hline Aspartate kinase (457 residues) & $448 / 449(100)$ & $450 / 452(100)$ & ND \\
\hline
\end{tabular}

${ }^{1}$ Identical AA/similar AA (\% query coverage).

${ }^{2}$ Predicted from coding sequence.

${ }^{3}$ Not detected in draft (incomplete) ATCC 15009 genome, but CGH data indicate the gene is present.

${ }^{4}$ Basic Local Alignment Search Tool (BLAST; http://blast.ncbi.nlm.nih.gov/Blast.cgi) searches for ornithine carbamoyltransferase, carbamate kinase, and arginine deiminase were performed using protein sequences from GenBank files ADZ07496, YP_004032111, and ADZ07497, respectively.

${ }^{5}$ Partial or interrupted gene located near end of a sequence contig in the draft assembly. Full reading frame may or may not be intact.

${ }^{6}$ Predicted protein sequence from DPC 4571 ortholog used for homology comparisons.

${ }^{7}$ Predicted protein sequence from $\mathrm{H} 10$ ortholog used for homology comparisons.

has been noted among $L b$. helveticus in regard to AA metabolism results from the combination of gene inactivation and sequence polymorphisms that alter the specificity or relative activity of individual enzymes.

\section{CONCLUSIONS}

Lactobacillus helveticus is recognized among LAB for its proteolytic activity and rich assortment of proteo- lytic enzymes (Gilbert et al., 1997; Christensen et al., 1999; Matar et al., 2001; Savijoki et al., 2006). Interest in the proteolytic system of this bacterium is tied to its ability to decrease bitterness and accelerate flavor development in cheese (Bartels et al., 1987a,b; Ardö and Pettersson, 1988; Drake et al., 1996) and to release bioactive peptides in milk-based foods (Laffineur et al., 1996; LeBlanc et al., 2002; Hayes et al., 2007b; Gobbetti et al., 2010). However, these attributes are strain 
specific, and more detailed knowledge of the proteolytic enzyme systems and AA catabolism in Lb. helveticus is needed to better use these organisms for food and health. Results from this study suggest strain heterogeneity in peptidase activity or AA metabolism are not based on differences in gene content, but rather are more likely due to a combination of nonsense mutations plus sequence polymorphisms that affect the expression level, specificity, or activity of the individual enzymes involved in these reactions. In contrast, marked genetic differences were discovered in the distribution of CEP paralogs, and those differences are probably very important determinants of strain functionality in cheese and in production of bioactive peptides in fermented milks.

\section{ACKNOWLEDGMENTS}

The authors thank Julie Audy (Institut Rosell, Montreal, QC, Canada) for technical assistance with the multiplex PCR analysis, Marie Penderup Jensen (University of Copenhagen, Frederiksberg C, Denmark) for assistance with DNA extraction for CGH, Craig Brighton (Utah State University, Logan) for assistance with growth experiments in cheese whey, Theresa Walunas and Integrated Genomics (Mount Prospect, IL) for assistance in designing the $L b$. helveticus CNRZ 32 microarray, the Utah State University (USU) Center for Integrated Biosystems for microarray hybridizations and scanning (Logan), and John R. Stevens of the USU Mathematics and Statistics Department (Logan) for help with $\mathrm{R}$ bioinformatics software. We also thank Sarah Highlander (Baylor College of Medicine, Houston, TX) and the Human Microbiome Project Reference Genome Sequencing Initiative, U54 HG003273, for assistance with access to the Lb. helveticus ATCC 15009 (DSM 20075) draft genome sequence. Portions of this research were supported by the United States Department of Agriculture, by Dairy Management Inc. [through the Center for Dairy Research (Madison, MI) and Western Dairy Center (Logan, UT)], and by the Utah Agricultural Experiment Station (Logan).

\section{REFERENCES}

Anukam, K. C., E. O. Osazuwa, I. Ahonkhai, and G. Reid. 2006. Lactobacillus vaginal microbiota of women attending a reproductive health care service in Benin City, Nigeria. Sex. Transm. Dis. 33:59-62.

Ardö, Y. 2006. Flavour formation by amino acid catabolism. Biotechnol. Adv. 24:238-242.

Ardö, Y., and H.-E. Pettersson. 1988. Accelerated cheese ripening with heat treated cells of Lactobacillus helveticus and a commercial proteolytic enzyme. J. Dairy Res. 55:239-245.

Azarnia, S., N. Robert, and B. Lee. 2006. Biotechnological methods to accelerate cheddar cheese ripening. Crit. Rev. Biotechnol. 26:121-143.
Bartels, H. J., M. E. Johnson, and N. F. Olson. 1987a. Accelerated ripening of Gouda cheese. I. Effect of heat-shocked thermophilic lactobacilli and streptococci on proteolysis and flavor development. Milchwissenschaft 42:83-88.

Bartels, H. J., M. E. Johnson, and N. F. Olson. 1987b. Accelerated ripening of Gouda cheese. II. Effect of freeze-shocked Lactobacillus helveticus on proteolysis and flavor development. Milchwissenschaft 42:139-143.

Bolstad, B. M., F. Collin, J. Brettschneider, K. Simpson, L. Cope, R A. Irizarry, and T. P. Speed. 2005. Quality assessment of Affymetrix GeneChip data. Pages 33-48 in Bioinformatics and Computational Biology Solutions Using R and Bioconductor. R. Gentleman, V. Carey, W. Huber, R. Irizarry, and S. Dudoit, ed. Springer, New York, NY.

Bolstad, B. M., R. A. Irizarry, M. Åstrand, and T. P. Speed. 2003 A comparison of normalization methods for high density oligonucleotide array data based on variance and bias. Bioinformatics 19:185-193.

Broadbent, J. R., M. Barnes, C. Brennand, M. Strickland, K. Houck, M. E. Johnson, and J. L. Steele. 2002. Contribution of Lactococcus lactis cell envelope proteinase specificity to peptide accumulation and bitterness in reduced-fat Cheddar cheese. Appl. Environ. Microbiol. 68:1778-1785.

Broadbent, J. R., C. J. Oberg, H. Wang, and L. Wei. 1997. Attributes of the heat shock response in three species of dairy Lactobacillus. Syst. Appl. Microbiol. 20:12-19.

Broadbent, J. R., B. Rodriguez, P. Joseph, E. A. Smith, and J. L. Steele. 2006. Conversion of Lactococcus lactis cell envelope proteinase specificity by partial allele exchange. J. Appl. Microbiol. 100:1307-1317.

Broadbent, J. R., and J. L. Steele. 2007. Proteolytic enzymes of lactic acid bacteria and their influence on bitterness in bacterial-ripened cheeses. Pages 193-204 in Flavor of Dairy Products. K. R. Cadwallader, M. Drake, and R. J. McGorrin, ed. Amer. Chem. Soc., Washington, DC

Cachat, E., and F. G. Priest. 2005. Lactobacillus suntoryeus sp. nov. isolated from malt whisky distilleries. Int. J. Syst. Evol. Microbiol. $55: 31-34$.

Cai, H., R. Thompson, J. R. Broadbent, and J. L. Steele. 2009. Genome sequence and comparative genome analysis of Lactobacillus casei: Insights into their niche-associated evolution. Genome Biol. Evol. 1:239-257.

Callanan, M., P. Kaleta, J. O'Callaghan, O. O'Sullivan, K. Jordan, O. McAuliffe, A. Sangrador-Vegas, L. Slattery, G. F. Fitzgerald, T. Beresford, and R. P. Ross. 2008. Genome sequence of Lactobacillus helveticus, an organism distinguished by selective gene loss and insertion sequence element expansion. J. Bacteriol. 190:727-735.

Chen, Y.-S., J. E. Christensen, J. R. Broadbent, and J. L. Steele. 2003. Identification and characterization of Lactobacillus helveticus $\mathrm{PepO} 2$, an endopeptidase with post-proline specificity. Appl. Environ. Microbiol. 69:1276-1282.

Christensen, J. E., E. G. Dudley, J. R. Pederson, and J. L. Steele. 1999. Peptidases and amino acid catabolism in lactic acid bacteria. Antonie van Leeuwenhoek 76:217-246.

Christensen, J. E., and J. L. Steele. 2003. Impaired growth rates of Lactobacillus helveticus peptidase mutants can be overcome by mutant-specific amino acid supplements. J. Bacteriol. 185:32973306.

Christiansen, J. K., J. E. Hughes, D. L. Welker, B. T. Rodríguez, J. L. Steele, and J. R. Broadbent. 2008. Phenotypic and genotypic analysis of amino acid auxotrophy in Lactobacillus helveticus CNRZ 32. Appl. Environ. Microbiol. 74:416-423.

Cogan, T. M., T. P. Beresford, J. L. Steele, J. Broadbent, N. P. Shah, and Z. Ustunol. 2007. Invited review: Advances in starter cultures and cultured foods. J. Dairy Sci. 90:4005-4021.

de Moreno de LeBlanc, A., C. Matar, C. Thériault, and G. Perdigón. 2005. Effects of milk fermented by Lactobacillus helveticus R389 on immune cells associated to mammary glands in normal and a breast cancer model. Immunobiology 210:349-358.

Deutsch, S.-M., D. Molle, V. Gagnaire, M. Piot, D. Atlan, and S. Lortal. 2000. Hydrolysis of sequenced $\beta$-casein peptides provides new 
insight into peptidase activity from thermophilic lactic acid bacteria and highlights intrinsic resistance of phosphopeptides. Appl. Environ. Microbiol. 66:5360-5367.

Dias, B., and B. Weimer. 1998. Conversion of methionine to thiols by lactococci, lactobacilli, and brevibacteria. Appl. Environ. Microbiol. 64:3320-3326.

Drake, M. A., T. D. Boylston, and B. G. Swanson. 1996. Chemical and sensory effects of a Lactobacillus adjunct in cheddar cheese. Food Res. Int. 29:381-387.

Fox, P. F. 1989. Proteolysis during cheese manufacture and ripening. J. Dairy Sci. 72:1379-1400.

Gatti, M., C. Lazzi, L. Rossetti, G. Mucchetti, and E. Neviani. 2003. Biodiversity in Lactobacillus helveticus strains present in natural whey starter used for Parmigiano Reggiano cheese. J. Appl. Microbiol. 95:463-470.

Gatti, M., C. Trivisano, E. Fabrizi, E. Neviani, and F. Gardini. 2004. Biodiversity among Lactobacillus helveticus strains isolated from different natural whey starter cultures as revealed by classification trees. Appl. Environ. Microbiol. 70:182-190.

Genay, M., L. Sadat, V. Gagnaire, and S. Lortal. 2009. prtH2, not prt $H$, is the ubiquitous cell wall proteinase gene in Lactobacillus helveticus. Appl. Environ. Microbiol. 75:3238-3249.

Gilbert, C., B. Blanc, J. Frot-Coutaz, R. Portalier, and D. Atlan. 1997. Comparison of cell surface proteinase activities within the Lactobacillus genus. J. Dairy Res. 64:561-571.

Gobbetti, M., R. D. Cagno, and M. De Angelis. 2010. Functional microorganisms for functional food quality. Crit. Rev. Food Sci. Nutr. 50:716-727.

Gobbetti, M., L. Stepaniak, M. De Angelis, A. Corsetti, and R. Di Cagno. 2002. Latent bioactive peptides in milk proteins: Proteolytic activation and significance in dairy processing. Crit. Rev. Food Sci. Nutr. 42:223-239.

Gummalla, S., and J. R. Broadbent. 1999. Tryptophan catabolism by Lactobacillus casei and Lactobacillus helveticus cheese flavor adjuncts. J. Dairy Sci. 82:2070-2077.

Hassan, A. N., and J. F. Frank. 2001. Starter cultures and their use. Pages 151-207 in Applied Dairy Microbiology. E. H. Marth and J. L. Steele, ed. Marcel Dekker, New York, NY.

Hayes, M., C. Stanton, G. F. Fitzgerald, and R. P. Ross. 2007a. Putting microbes to work: Dairy fermentation, cell factories and bioactive peptides. Part I: Overview. Biotechnol. J. 2:426-434.

Hayes, M., C. Stanton, G. F. Fitzgerald, and R. P. Ross. 2007b. Putting microbes to work: Dairy fermentation, cell factories and bioactive peptides. Part II: Bioactive peptide functions. Biotechnol. J. 2:435-449.

Hermans, P. W. M., P. V. Adrian, C. Albert, S. Estevão, T. Hoogenboezem, I. H. T. Luijendijk, T. Kamphausen, and S. Hammerschmidt. 2006. The streptococcal lipoprotein rotamase A (SlrA) is a functional peptidyl-prolyl isomerase involved in pneumococcal colonization. J. Biol. Chem. 281:968-976.

Jacobs, M., J. B. Andersen, V. Kontinen, and M. Sarvas. 1993. Bacillus subtilis PrsA is required in vivo as an extracytoplasmic chaperone for secretion of active enzymes synthesized either with or without pro-sequences. Mol. Microbiol. 8:957-966.

Jensen, M. P., and Y. Ardö. 2010. Variation in aminopeptidase and aminotransferase activities of six cheese related Lactobacillus helveticus strains. Int. Dairy J. 20:149-155.

Jensen, M. P., F. K. Vogensen, and Y. Ardö. 2009. Variation in caseinolytic properties of six cheese related Lactobacillus helveticus strains. Int. Dairy J. 19:661-668.

Kandler, O., and N. Weiss. 1986. Genus Lactobacillus. Pages 12091234 in Bergey's Manual of Systematic Bacteriology. Vol. 2. P. H. A. Sneath, N. S. Mair, M. E. Sharpe, and J. G. Holt, ed. Williams and Wilkins, Baltimore, MD.

Kilpi, E. E.-R., M. M. Kahala, J. L. Steele, A. M. Pihlanto, and V. V. Joutsjoki. 2007. Angiotensin I-converting enzyme inhibitory activity in milk fermented by wild-type and peptidase-deletion derivatives of Lactobacillus helveticus CNRZ 32. Int. Dairy J. 17:976-984.
Klein, N., M.-B. Maillard, A. Thierry, and S. Lortal. 2001. Conversion of amino acids into aroma compounds by cell-free extracts of Lactobacillus helveticus. J. Appl. Microbiol. 91:404-411.

Kontinen, V. P., P. Saris, and M. Sarvas. 1991. A gene (prsA) of Bacillus subtilis involved in a novel, late stage of protein export. Mol. Microbiol. 5:1273-1283.

Kunji, E. R. S., I. Mierau, A. Hagting, B. Poolman, and W. N. Konings. 1996. The proteolytic system of lactic acid bacteria. Antonie van Leeuwenhoek 70:187-221.

Laan, H., S. E. Tan, P. Bruinenberg, G. Limsowtin, and M. Broome. 1998. Aminopeptidase activities of starter and non-starter lactic acid bacteria under simulated Cheddar cheese ripening conditions. Int. Dairy J. 8:267-274.

Laffineur, E., N. Genetet, and J. Leonil. 1996. Immunomodulatory activity of beta-casein permeate medium fermented by lactic acid bacteria. J. Dairy Sci. 79:2112-2120.

LeBlanc, J. G., C. Matar, J. C. Valdéz, J. LeBlanc, and G. Perdigon. 2002. Immunomodulating effects of peptidic fractions issued from milk fermented with Lactobacillus helveticus. J. Dairy Sci. 85:2733-2742.

Leclerc, P.-L., S. F. Gauthier, H. Bachelard, M. Santure, and D. Roy. 2002. Antihypertensive activity of casein-enriched milk fermented by Lactobacillus helveticus. Int. Dairy J. 12:995-1004.

Lee, W.-J., D. S. Banavara, J. E. Hughes, J. K. Christiansen, J. L. Steele, J. R. Broadbent, and S. A. Rankin. 2007. Role of cystathionine $\beta$-lyase in amino acid catabolism to sulfur volatiles by genetic variants of Lactobacillus helveticus CNRZ 32. Appl. Environ. Microbiol. 73:3034-3039.

Liu, M., J. R. Bayjanov, B. Renckens, A. Nauta, and R. J. Siezen. 2010. The proteolytic system of lactic acid bacteria revisited: A genomic comparison. BMC Genomics 11:36.

Matar, C., J. C. Valdez, M. Medina, M. Rachid, and G. Perdigon. 2001. Immunomodulating effects of milks fermented by Lactobacillus helveticus and its non-proteolytic variant. J. Dairy Res. 68:601-609.

Minervini, F., F. Algaron, C. G. Rizzello, P. F. Fox, V. Monnet, and M. Gobbetti. 2003. Angiotensin I-converting-enzyme-inhibitory and antibacterial peptides from Lactobacillus helveticus PR4 proteinase-hydrolyzed caseins of milk from six species. Appl. Environ. Microbiol. 69:5297-5305.

Nagradova, N. 2007. Enzymes catalyzing protein folding and their cellular functions. Curr. Protein Pept. Sci. 8:273-282.

Naser, S. M., K. E. Hagen, M. Vancanneyt, I. Cleenwerck, J. Swings, and T. A. Tompkins. 2006. Lactobacillus suntoryeus Cachat and Priest 2005 is a later synonym of Lactobacillus helveticus (OrlaJensen 1919) Bergey et al. 1925 (Approved Lists 1980). Int. J. Syst. Evol. Microbiol. 56:355-360.

Oberg, C. J., J. R. Broadbent, M. Strickland, and D. J. McMahon. 2002. Diversity in specificity of the extracellular proteinases in Lactobacillus helveticus and Lactobacillus delbrueckii ssp. bulgaricus. Lett. Appl. Microbiol. 34:455-460.

Oommen, B. S., D. J. McMahon, C. J. Oberg, J. R. Broadbent, and M. Strickland. 2002. Proteolytic specificity of Lactobacillus delbrueckii ssp. bulgaricus influences functional properties of Mozzarella cheese. J. Dairy Sci. 85:2750-2758.

Pederson, J. A., G. J. Mileski, B. C. Weimer, and J. L. Steele. 1999. Genetic characterization of a cell envelope-associated proteinase from Lactobacillus helveticus CNRZ32. J. Bacteriol. 181:45924597.

Pettersson, H.-E., and G. Sjöström. 1975. Accelerated cheese ripening: A method for increasing the number of lactic acid bacteria in cheese without detrimental effect to the cheese-making process, and its effect on cheese. J. Dairy Res. 42:313-326.

Pillidge, C. J., V. L. Crow, T. Coolbear, and J. R. Reid. 2003. Exchanging lactocepin plasmids in lactococcal starters to study bitterness development in Gouda cheese: A preliminary investigation. Int. Dairy J. 13:345-354.

Rahfeld, J.-U., K. P. Rücknagel, B. Schelbert, B. Ludwig, J. Hacker, K. Mann, and G. Fischer. 1994. Confirmation of the existence of a third family among peptidyl-prolyl cis/trans isomerases. Amino 
acid sequence and recombinant production of parvulin. FEBS Lett. 352:180-184.

Saeed, A. I., V. Sharov, J. White, J. Li, W. Liang, N. Bhagabati, J. Braisted, M. Klapa, T. Currier, M. Thiagarajan, A. Sturn, M. Snuffin, A. Rezantsev, D. Popov, A. Ryltsov, E. Kostukovich, I. Borisovsky, Z. Liu, A. Vinsavich, V. Trush, and J. Quackenbush. 2003. TM4: A free, open-source system for microarray data management and analysis. Biotechniques 34:374-378.

Sasaki, M., B. W. Bosman, and P. S. Tan. 1995. Comparison of proteolytic activities in various lactobacilli. J. Dairy Res. 62:601-610.

Savijoki, K., H. Ingmer, and P. Varmanen. 2006. Proteolytic systems of lactic acid bacteria. Appl. Microbiol. Biotechnol. 71:394-406.

Siezen, R. J. 1999. Multi-domain, cell-envelope proteinases of lactic acid bacteria. Antonie van Leeuwenhoek 76:139-155.

Smeianov, V. V., P. Wechter, J. R. Broadbent, J. E. Hughes, B. Rodriguez, T. K. Christensen, Y. Ardö, and J. L. Steele. 2007. Comparative high-density microarray analysis of gene expression during growth of Lactobacillus helveticus in milk versus rich culture medium. Appl. Environ. Microbiol. 73:2661-2672.

Soeryapranata, E., J. R. Powers, and G. Ünlü. 2007. Cloning and characterization of debittering peptidases, PepE, PepO, PepO2, PepO3, and PepN, of Lactobacillus helveticus WSU19. Int. Dairy J. 17:1096-1106.

Sridhar, V. R., J. E. Hughes, D. L. Welker, J. R. Broadbent, and J. L. Steele. 2005. Identification of endopeptidase genes from the ge- nomic sequence of Lactobacillus helveticus CNRZ32 and their role in hydrolysis of model bitter peptides. Appl. Environ. Microbiol. 71:3025-3032.

Stoyancheva, G. D., S. T. Danova, and I. Y. Boudakov. 2006. Molecular identification of vaginal lactobacilli isolated from Bulgarian women. Antonie van Leeuwenhoek 90:201-210.

Vitali, B., M. Ndagijimana, F. Cruciani, P. Carnevali, M. Candela, M. E. Guerzoni, and P. Brigidi. 2010. Impact of a synbiotic food on the gut microbial ecology and metabolic profiles. BMC Microbiol. 10:4.

Weimer, B., B. Dias, M. Ummadi, J. Broadbent, C. Brennand, J. Jaegi, M. Johnson, F. Milani, J. Steele, and D. V. Sisson. 1997. Influence of $\mathrm{NaCl}$ and $\mathrm{pH}$ on intracellular enzymes that influence Cheddar cheese ripening. Lait 77:383-398.

Yamamoto, N., A. Akino, and T. Takano. 1994. Antihypertensive effect of the peptides derived from casein by an extracellular proteinase from Lactobacillus helveticus CP790. J. Dairy Sci. 77:917-922.

Yvon, M., and L. Rijnen. 2001. Cheese flavour formation by amino acid catabolism. Int. Dairy J. 11:185-201.

Zhao, W. Y. Chen, Z. Sun, J. Wang, Z. Zhou, T. Sun, L. Wang, W. Chen, and H. Zhang. 2011. Complete genome sequence of the Lactobacillus helveticus H10. J. Bacteriol. 193:2666-2667. doi:10.1128/JB.00166-11. 